\title{
ANALYSIS OF SPEECH ACTS IN SUSILO BAMBANG YUDHOYONO'S POLITICAL SPEECH
}

\author{
Tesa Jatnika Permana1, Arham Mauriyat ${ }^{2}$ \\ IKIP Siliwangi \\ ${ }^{1}$ tesajatnikap@ student.ikipsiliwangi.ac.id, ${ }^{2}$ arham@ikipsiliwangi.ac.id
}

\begin{abstract}
Speech acts are utterances which do not only have explicit meaning but also implicit meaning. Political speech acts are such an important issue for politicians as they can provide information to regulate people's thoughts and opinions through political language which is used as the main key. This research examined speech acts' implementation in political speech, including the types of speech acts by politicians in political speech as well as their functions, in order to give a theoretical analysis about every utterance in political speech through context of meaning. The data were analyzed qualitatively where the researchers describe the results in the form of words and explanations by adopting Searle's theory. It was found that the types of speech acts that mostly appeared in Susilo Bambang Yudhoyono's political speech are nine assertives, eight commissives and four directives. Each type of the speech acts delivered a different context of meaning.
\end{abstract}

Keywords: Speech Acts, Political Speech, Illocutionary

\section{INTRODUCTION}

Language is a human communication system which consists of structured arrangements of sounds or their written representation into larger units, e.g. morphemes, words, sentences, utterances (Richards \& Schmidt, 2002, as cited in Swastiana, Putra, \& Suarnajaya, 2020). Intentional interaction during a political speech in a public place occurs between the politician and the people through language. Language styling is referred to language which has been mixed with stylistic elements, especially a figure of speechor language style (Rahayu \& Parmawati, 2020). The use of language in communication in particular situations needs a view of pragmatic study to take cognizance of the message being communicated or the speech act being carried out; the implicated participants; their intention, knowledge of the world and the effect of these on their interactions; what they have taken for granted as portion of the context; the conclusions they make on the basis of the context; what is implied by what is said or unsaid; etc. (Leech, 1983; Thomas, 1995; Watson \& Hill, 1993). Through speech, the speaker and listener establish communication properly to achieve better outcomes. Pragmatics is an important linguistic field which is associated with meaning and context (Fadilah, Meisuri, \& Pane, 2019). It can increase linguistic performances in communication such as linguistic knowledge, the utterance context, knowledge about the status of those involved, and the speaker's inferred intention are several issues which determine how the meaning of utterances is successfully transmitted.

In pragmatics, the language function is studied in speech acts (McCarthy, 1991). A speech act is an utterance which has both explicit and implicit meaning. The implicit meaning can be known from the actions taken by someone when performing a speech act. Rahayu, Syahrizal, and Sadikin (2019) state that speech acts are actions in language that arise when speaking something. According to other concepts of speech acts, every utterance basically holds three 
elements: locution, illocution, and perlocution. Locution is the uttecance of what the speaker says, illocution is the aim of what the speaker says, and perlocution is the impact of what the speaker says (Swastiana et al., 2020). Yule (1996) states that of those three components, illocution is the most discussed in pragmatics. The whole utterances which are used as a medium in political communication belong to political speech acts.

Political speech acts are very important for politicians as they can provide information to regulate people's thoughts and opinions through political language as the key. This is one of the spearheads for controlling people's minds, just as when exploring people's mindsets, offering ideas or policies, building community stigma, and convincing people of everything that is offered. Political speech is used to achieve all that, and what is done is usually based on the speaker's intention and the context of who delivers the speech and where it is delivered. The meaning of a political speech's utterance can be easy to understand and investigate if people know the context. Dylgjeri (2017) states that the function of political language expressed in society has a reciprocal relationship with the reality of political life in society.

Otherwise, people interested in political speech when discussing speech acts would face difficulties in understanding and investigating the meaning, because the language used in the political world is a persuasive limitation seeking to arouse emotive elements of listeners and readers. Moreover, euphemistic and hyperbolic languages that are often used in politics would eliminate the meaning that should be conveyed, while language in the political world is required to give accurate and clear meaning. The use of political language in society strongly follows the determination of language development in general (Dylgjeri, 2017). Language in political speech also contains implicit meaning through utterances in speech. Sometimes people misunderstand the speech that a speaker gives, and transform it into another meaning. Out-ofcontext comprehension frequently happens in political speech, making the utterance in the speech and people's thoughts not synchronized to each other.

Based on the explanation above and phenomena taking place in society about speech acts, the researchers sought to examine one political speech in Indonesia by focusing on speech act theory analysis in political speech. This research was conducted to investigate the implementation of speech acts in political speech, including the types and functions of speech acts used by politicians, in order to give a theoretical analysis about every utterance in political speech through context of meaning.

\section{Speech Act Theory}

Searle (1969) enhances Austin's speech act theory by recognizing two kinds of discourse acts: direct and indirect speech acts. Searle puts illocutionary demonstration into five classes:

1. Assertives: These are statements that represent a situation on the earth which could be right or wrong. They commit a speaker to the truth of the propositions expressed.

2. Directives: These are statements that compel or make someone else's action fit the propositional element. It is generally used to give order in this way making the listener make a specific move, request, command or advice.

3. Commissives: These statements submit the speaker to certain future activity. It could be as a guarantee.

4. Expressives: The aim of expressive statements is to express sincerity of the speech act like sympathy.

5. Declaratives: These statements are aimed to state something and make it so, for example, mentioning someone's mistake and declaring a war. 
The utilization of the speech act hypothesis in the investigation will permit inside-and-out examination into the linguistic highlights that have been examined to instill significance.

\section{METHOD}

The research was conducted by using qualitative research design to analyze the speech acts. According to Perry (2005, as cited in Dewi, Hernawan, \& Apsari, 2019), qualitative research is identified by the verbal description of its data. The data were taken from the political speech of Former President of Indonesia Prof. Dr. Susilo Bambang Yudhoyono at the 17th anniversary of Partai Demokrat (Democratic Party) entitled Utamakan Rakyat dan Bangun Politik yang Beradab (Prioritize the People and Build Civilized Politics) (Talk Show tvOne, 2018; Yudhoyono, 2018). The technique of collecting data applied in this research consists of analyzing every utterance in the speech's script and viewing the video to identify the speech acts that appear in the political speech with the speech theory of pragmatics.

\section{RESULTS AND DISCUSSION}

\section{Results}

Data obtained from the script can be seen in the table below.

Table 1. Speech acts resulting in Susilo Bambang Yudhoyono's political speech script

\begin{tabular}{cccc}
\hline No. & Speech Acts & Utterances & Total \\
\hline 1. & Assertives & Reporting (5), Stating (4) & 9 \\
\hline 2. & Directives & Advising (2), Commanding (2) & 4 \\
\hline 3. & Commissives & Testing (8) & 8 \\
\hline 4. & Expressives & - & - \\
\hline 5. & Declaratives & - & - \\
\hline
\end{tabular}

\section{Discussion}

The following results are based on utterances in Yudhoyono's (2018) political speech.

1. Locution: "Sekarang, saya akan menyampaikan hal lain yang tak kalah pentingnya, yaitu tentang pentingnya politik yang beradab di negeri kita."

(Now, I will say something else that is no less important, namely about the importance of civilized politics in our country.)

Illocutionary act: Assertive (reporting)

Expected perlocutionary effect: Awareness about the importance of civilized politics

2. Locution: "Esensi dari politik yang beradab adalah adanya kekuasaan yang amanah dan tidak korup dalam arti tidak disalahgunakannya kekuasaan itu; terjaminnya hak-hak politik rakyat termasuk kebebasan berbicara; demokrasi yang tertib, tidak anarkis dan taat pada pranata hukum; dan pers yang merdeka namun juga bertanggung jawab."

(The essence of civilized politics is the existence of powers that are trustworthy and not corrupt in the sense that they are not abused; the guarantee of people's political rights including freedom of speech; a democracy that is orderly, not anarchic and law-abiding; and independent but also responsible press.)

Illocutionary act: Assertive (stating) 
Expected perlocutionary effect: Hope for the essence of politics

3. Locution: "Politik juga "civilized", atau berkeadaban, jika semua menghormati sistem pergantian kepemimpinan politik, termasuk Presiden, dan tidak ada gerakan untuk menjatuhkan Presiden di tengah jalan secara inkonstitusional."

(Politics is also civilized, if all respect the system of change of political leadership, including the President, and there is no movement to overthrow the President in office unconstitutionally.)

Illocutionary act: Assertive (stating)

Expected perlocutionary effect: Awareness of civilized politics

4. Locution: "Kehidupan politik yang baik juga bebas dari represi kekuasaan terhadap rakyatnya."

(Good political life is also free from repression of power over its people.)

Illocutionary act: Assertive (reporting)

Expected perlocutionary effect: Hope for good political life

5. Locution: "Sementara, rakyat dengan dalih kebebasan juga tidak boleh melakukan tindakan melawan hukum serta mengganggu ketertiban dan keamanan publik."

(Meanwhile, the people under the pretext of freedom must also not act against the law and disturb public order and security.)

Illocutionary act: Directives (advising)

Expected perlocutionary effect: Awareness about obeying the law

6. Locution: "Kita terus membangun politik dan demokrasi yang makin matang, makin berkualitas dan akhirnya makin beradab. Kita juga terus diuji apakah dalam perjalanan bangsa ini, termasuk pemilu yang akan kita laksanakan, politik dan demokrasi yang beradab itu dapat kita jaga dan kembangkan."

(We continue to build politics and democracy that are more mature, have greater quality and are finally more civilized. We also continue to be tested whether in the course of this nation, including the election that we will carry out, we can protect and develop such civilized politics and democracy.)

Illocutionary act: Assertives (stating)

Expected perlocutionary effect: Hope in building good politics

7. Locution: "Menjelang Pemilihan Umum 2019, politik akan makin memanas. Banyak godaan dan ujian yang akan kita hadapi."

(Ahead of the 2019 General Election, politics will intensify. There are many temptations and tests we will face.)

Illocutionary act: Assertives (reporting)

Expected perlocutionary effect: Awareness of the 2019 General Election

8. Locution: "Negara kembali akan diuji apakah Pemilu 2019 ini dapat berlangsung secara damai, adil dan demokratis. Peaceful, free and fair election."

(The state will again be tested on whether the 2019 Election can take place peacefully, fairly and democratically. Peaceful, free and fair election.)

Illocutionary act: Commissives (testing)

Expected perlocutionary effect: Awareness of and hope for a peaceful, free and fair election

9. Locution: "Tiga pemilu sebelumnya Pemilu 2004, Pemilu 2009 dan Pemilu 2014, berlangsung secara damai, adil dan demokratis."

(The three previous elections the 2004 Election, 2009 Election and 2014 Election, took place in a peaceful, fair and democratic manner.)

Illocutionary act: Assertives (reporting)

Expected perlocutionary effect: Inspiration to create a peaceful, free and fair election

10. Locution: Sejarah akan menguji apakah negara dapat mempertahankan prestasi ini."

(History will test whether the state can maintain this achievement.) 
Illocutionary act: Commissives (testing)

Expected perlocutionary effect: Hope for political achievement

11. Locution: "Kita akan diuji, apakah untuk meraih kemenangan dalam pemilu, ada yang tergoda menghalalkan segala cara. Termasuk menyalahgunakan kekuasaan, melanggar Undang-Undang serta menghalang-halangi pihak lain untuk menjalankan kampanye pemilu yang semestinya."

(We will be tested, whether to achieve victory in the election, there are those tempted to justify any means. Including abusing power, violating laws and obstructing other parties from carrying out appropriate election campaigns.)

Illocutionary act: Commissives (testing)

Expected perlocutionary effect: Awareness of achievement in the election

12. Locution: "Kita akan diuji apakah pemilu ini bisa mencegah politik uang (money politics) yang makin menjadi-jadi."

(We will be tested on whether this election can prevent money politics from worsening.)

Illocutionary act: Commissives (testing)

Expected perlocutionary effect: Encouragement to prevent money politics

13. Locution: "Demokrasi akan runtuh dan rakyat akan dikebiri manakala uang menjadi penentu segala-galanya. Gelap politik kita kalau uang digunakan sebagai alat untuk membeli suara rakyat dan juga sebagai transaksi terbangunnya koalisi partai-partai."

(Democracy will collapse and the people will be castrated when money determines everything. Dark will our politics be if money is used as a tool to buy people's votes and also as a transaction to build coalitions of parties.)

Illocutionary act: Assertives (stating)

Expected perlocutionary effect: Awareness of democracy

14. Locution: "Kita akan diuji apakah pemilu ini bebas dari intimidasi yang akan mengganggu kedaulatan rakyat untuk menjatuhkan pilihannya."

(We will be tested whether this election is free from intimidation that will disrupt the sovereignty of the people in making their choice.)

Illocutionary act: Commissives (testing)

Expected perlocutionary effect: Awareness of preventing intimidation

15. Locution: "Kekuatan atau power yang dimiliki oleh siapapun tidaklah boleh untuk mengintimidasi dan memaksa seseorang agar memilih kandidat atau partai politik tertentu."

(Any strength or power possessed by anyone must not be allowed to intimidate and force someone to choose a particular candidate or political party.)

Illocutionary act: Directives (advising)

Expected perlocutionary effect: Awareness of justice

16. Locution: "Kita akan diuji apakah politik identitas yang melebihi takarannya akan dimainkan oleh para kandidat dan partai-partai politik peserta pemilu."

(We will be tested on whether identity politics that exceeds its dose will be played by candidates and political parties participating in the election.)

Illocutionary act: Commissives (testing)

Expected perlocutionary effect: Awareness of limiting identity politics

17. Locution: "Di negara manapun, selalu ada korelasi antara identitas dengan preferensi pemilihan dan politik. Namun, apabila melebihi kepatutannya dan secara membabi buta dijadikan "penentu” untuk memilih seseorang ataupun partai politik tertentu, demokrasi kita akan mundur jauh ke belakang."

(In any country, there is always a correlation between identity and election and political preferences. However, if it exceeds its propriety and is blindly used as a "determinant" in choosing a particular person or political party, our democracy will move far back.) 
Illocutionary act: Assertives (reporting)

Expected perlocutionary effect: Awareness of democracy

18. Locution: "Kita akan diuji apakah pers dan media massa bisa bertindak adil dan memberikan ruang yang berimbang bagi para kandidat dan kontestan peserta pemilu."

(We will be tested on whether the press and mass media can act fairly and provide a balanced space for the candidates and contestants participating in the election.)

Illocutionary act: Commissives (testing)

Expected perlocutionary effect: Hope for and awareness of fair media coverage

19. Locution: "Media massa adalah milik rakyat, milik kita semua. Janganlah media massa tidak lagi independen dan berimbang dalam pemberitaannya lantaran tekanan pemilik modal dan pihak-pihak tertentu."

(The mass media belong to the people, to all of us. Don't let the mass media no longer be independent and balanced in their reporting because of the pressure of stakeholders and certain parties.)

Illocutionary act: Directives (commanding)

Expected perlocutionary effect: Encouragement to the media

20. Locution: "Dan kita akan diuji, apakah perangkat negara termasuk intelijen, kepolisian dan militer netral dan tidak berpihak."

(And we will be tested, whether the state apparatus including the intelligence, police and military are neutral and impartial.)

Illocutionary act: Commissives (testing)

Expected perlocutionary effect: Awareness of state apparatus being neutral

21. Locution: "Ingat, TNI, Polri dan BIN adalah milik negara, milik rakyat Indonesia. Akan mencederai sumpah dan etikanya kalau aparat negara tidak netral. Sebagai salah satu pelaku reformasi, saya ingatkan TNI, Polri dan BIN harus belajar dari sejarah, bahwa karena kesalahan masa lampaunya, rakyat terpaksa memberikan koreksi."

(Remember, TNI, Polri and BIN belong to the state property, to the people of Indonesia. It will injure their oaths and ethics if the state apparatus are not neutral. As one of the reformers, I remind TNI, Polri and BIN to learn from history, that because of their past mistakes, the people were forced to make corrections.)

Illocutionary act: Directives (commanding)

Expected perlocutionary effect: Awareness of state apparatus being neutral and inspired by history

\section{CONCLUSION}

According to the results of this study, it can be seen that the types of speech acts in Susilo Bambang Yudhoyono's political speech are mostly assertives comprising nine utterances with five reporting statements and four stating statements, which mean that the speaker wanted to portray a factual current situation. The second most are commissives at eight utterances that showed testing statements, implying that the speaker intended to test and ensure certain future actions. Next are directives at four utterances with two advising statements and two commanding statements, which suggest that the speaker sought a way to make the listeners take specific moves and follow specific demands, orders or counsel. The fewest are expressives and declaratives with zero utterance, indicating that the speaker did not aim to express sincerity nor to give any declaration such as mentioning somebody's mistake or proclaiming a war. 


\section{ACKNOWLEDGMENTS}

The researchers send all praise to Allah for the completion of this research and all of the efforts that the researchers have put in this project granted by Allah. The researchers would also like to thank IKIP Siliwangi for giving the opportunity to publish this research.

\section{REFERENCES}

Dewi, M. W., Hernawan, K. F., \& Apsari, Y. (2019). Thematic progression in students' descriptive texts. Project, 2(2), 227-233. http://dx.doi.org/10.22460/project.v2i2.p227233

Dylgjeri, A. (2017). Analysis of speech acts in political speeches. European Journal of Social Sciences Studies, 2(2), 19-26. https://doi.org/10.5281/zenodo.344518

Leech, G. N. (1983). Principles of pragmatics. Longman.

Meisuri, T. F., \& Pane, I. I. I. (2019). Indirect speech acts in Toba Dream movie. Linguistica, 8(4), 220-226. https://doi.org/10.24114/jalu.v8i4.17036

McCarthy, M. (1991). Discourse analysis for language teachers. Cambridge University Press.

Rahayu, N. N., \& Parmawati, A. (2020). The Analysis of Language Style And The Illocutionary Act Found in Teen Lit Novel "The Perfect Husband" Written By Indah Riyana. PROJECT (Professional Journal of English Education), 3(3), 408-413.

Rahayu, A. S., Syahrizal, T., \& Sadikin, I. S. (2019). Speech act analysis of "Frozen" the movie script. Project, 2(5), 692-699. http://dx.doi.org/10.22460/project.v2i5.p692-699

Searle, J. R. (1969). Speech acts: An essay in the philosophy of language. Cambridge University Press.

Swastiana, N. M. I., Putra, I. N. A. J., \& Suarnajaya, I. W. (2020). An analysis of speech acts used by the seventh-grade teacher of SMPN 2 Bangli in EFL classroom interaction. Journal of Education Research and Evaluation, 4(1), 49-58. http://dx.doi.org/10.23887/jere.v4i1.23542

Talk Show tvOne. (2018, September 18). Pidato Politik SBY: "Utamakan Rakyat dan Bangun Politik Yang Beradab" [Video]. https://www.youtube.com/watch?v=BtuYZdrWvFA

Thomas, J. (1995). Meaning in interaction: An introduction to pragmatics. Longman.

Watson, J., \& Hill, A. (1993). A dictionary of communication and media studies (3rd ed.). Edward Arnold.

Yudhoyono, S. B. (2018, September 17). Pidato politik Prof. Dr. Susilo Bambang Yudhoyono pada acara 17 Tahun Partai Demokrat. Dewan Pimpinan Pusat Partai Demokrat. http://www.demokrat.or.id/s32j78lr2/pidato-politik-prof-dr-susilo-bambang-yudhoyonopada-acara-17-tahun-partai-demokrat/

Yule, G. (1996). Pragmatics. Oxford University Press. 